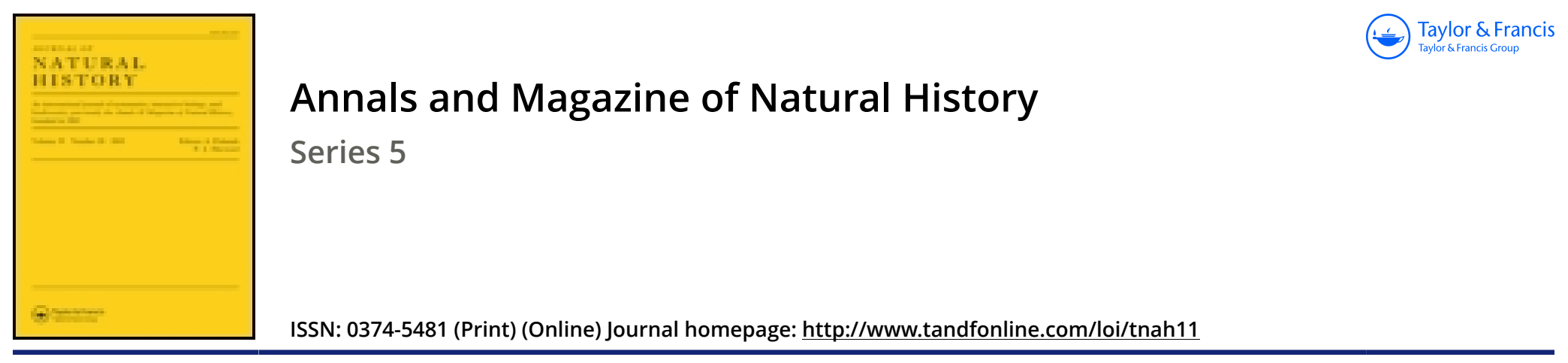

\title{
VIII.-On a new species of Schutzia from the Calciferous Sandstones of Scotland
}

\section{Robert Kidston F.G.S.}

To cite this article: Robert Kidston F.G.S. (1884) VIII._On a new species of Schutzia from the Calciferous Sandstones of Scotland , Annals and Magazine of Natural History, 13:74, 77-80, DOI: $10.1080 / 00222938409459203$

To link to this article: http://dx.doi.org/10.1080/00222938409459203

$$
\text { 曲 Published online: } 07 \text { Oct } 2009 .
$$

\section{Submit your article to this journal $₫$}

Џ Article views: 3

Q View related articles $₫$

4 Citing articles: 1 View citing articles 준 
VIII.-On a new Species of Schutzia fiom the Calciferous Sandstones of Scotland. By RoBERT KIDSTON, F.G.S.*

[Plate V. fig. 2.]

\section{Schutzia Bennieana, n. s., Kidst.}

Specific character.-Fruit campanulate, composed of linear lanceolate bracts; pedicels of fruits short and placed spirally on the axis.

Remarks.-The specimen on which the above description is based, shows the upper portion of a fructification, but its lower part is broken over, so that its original length cannot now be determined. The part which has been preserved is $3 \frac{3}{11}$ inches long.

Only three fruits are attached to the stem, the terminal one and two immediately beneath it.

Below these are seen the scars from which four others have fallen. The spiral arrangement of the fruits is clearly shown by the position of those which still remain, that on the right being placed at about a third of the circumference of the stem distant from the one to the left hand.

The bracts of the little cones are about half an inch long, narrow, and terminating in a sharp point, and they appear to have had a central keel. From the compressed state of the fossil it is impossible to make out their arrangement clearly, but they were probably placed in a few spirals.

The stalks to which they are attached are short, being barely, in the longest and lowest example, the fifth of an inch long. The main axis is irregularly striated longitudinally.

Affinities.-This plant is closely related to Schutzia anomala, Geinitz $\dagger$, from the Rothliegenden of Ottendorf, near Braunau, Bohemia $\ddagger$; but the differences between the Permian and the Scotch plant are such as to necessitate a specitic designation.

* Read before the Royal Physical Society of Edinburgh, December 19, 1883 .

$\uparrow$ Geinitz, Neues Jahrbuch, 1863, "Ueber zwei neue dyadische Pflanzen," p. 525, pl. vi. figs. $1,2,3$.

$f$ Goppert also notes the occurrence of this plant at Neurode, Silesia, see 'Die toss. Flora der permischen Formation,' pl. xxiii. figs. 1-6, pl. xxir. figs. $1,2,3,5(1864-5)$. The plates for this work were prepared before the publication of the paper by Geinitz, though not issued till after; hence the name which Göppert had proposed for this plant (Anthodhopsis Beinertina) appears on his plates; Sichutzia anomala, Gein., is used in his text. Sce also Göppert, Fos. Flora d. Uebergangsgebirges, p. 214, (1852). 
Ann \& Mag. Nat. Hist. S.5, Vot 13, Pl. T.

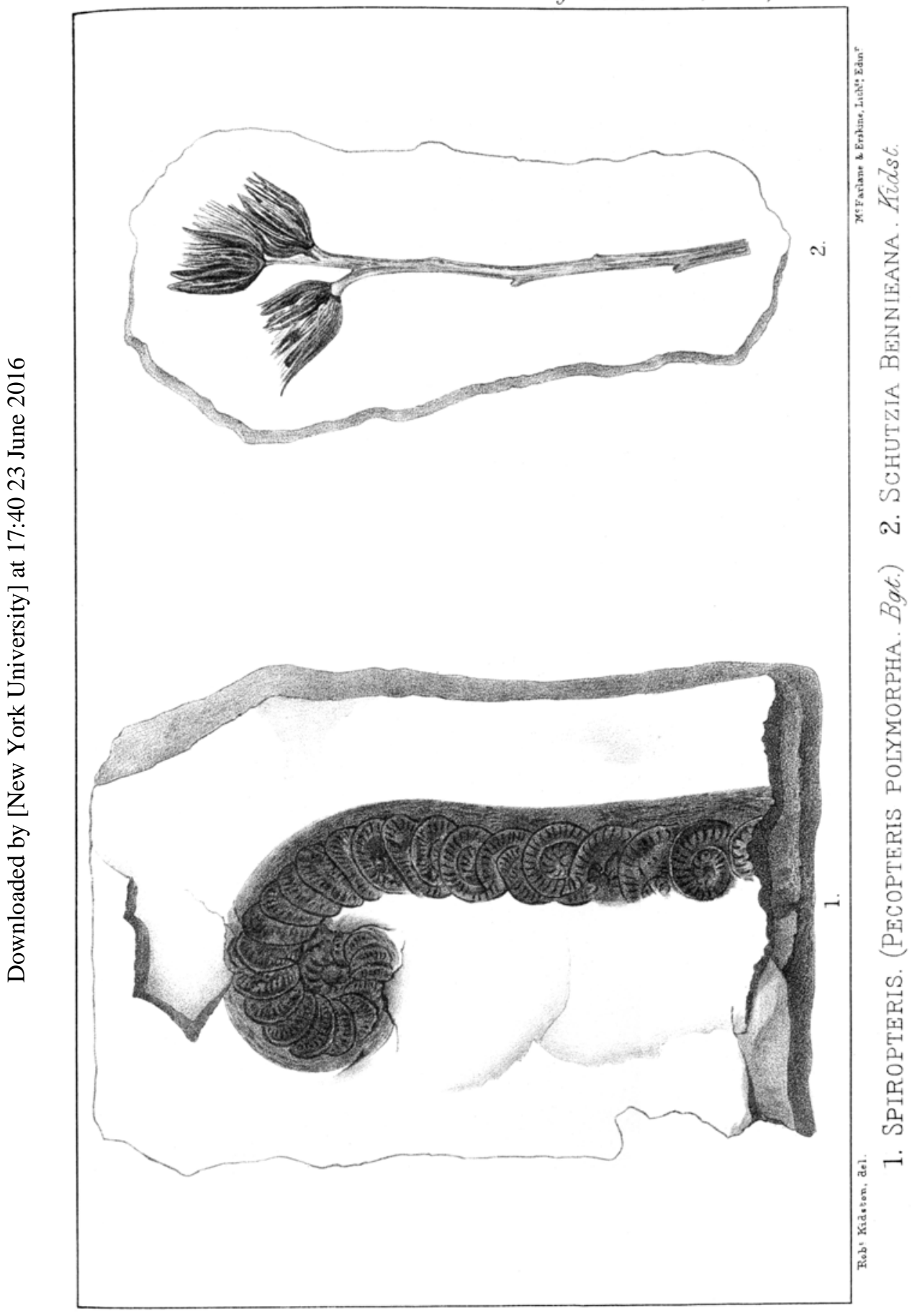


They agree in the spiral arrangement of the little cones, in their being short-stalked, and in the furrowed stem, as also in the angle made by the pedicels and the stem.

The form of the fruit is, however, essentially distinct.

In Schutzia anomala they are globular, and consist of numerous and much shorter keeled scales, which are similarly arranged in a few short rows. These often appear blunt, but Geinitz thinks this bluntness may arise through a bending of their apices.

Schutzia Bennieana teaches nothing as regards internal structure; but in S. anomala, Geinitz thought he could discover, "at the base of the inner side of the fruit-scales, the appearance on each side of a longitudinal depression, which corresponded to the two seeds in the fruit-scales of Ccniferæ."

In addition to the plates of Schutzia given by Göppert, he also figured another fossil, which he named Dictyothalamus Schrollianus.

This he thought might belong to Schutzia anomala, the latter being the female, the former the male plant. These occurred together and often on the same slab.

The central part of Dictyothalamus is composed of small elongated roundish bodies, which Göppert thought were the seeds.

He believed these fossils might belong to the Noggerathice, but Geinitz regarded them as coniferous.

As there occurred with the specimens Noggerathia (Cordaites) and Coniferæ of different genera, as Walchia piniformis, Schl., sp., and Ullmannia, no light is thrown on the affinities of Schutzia by the vegetable remains with which it was associated.

But that it does not belong to Walchia or Ullmannia is pretty certain, as the fruits of both these plants are now well knownt.

Schimper unites Dictyothalanus Schrollianus, Göpp., with Schutzia anomala, Geinitz $\downarrow$, and regards the Schutzia as the female, and the Dictyothalamus as the male plant. The

* Göppert, Die fos. Flora d. perm. Formation, p. 164, pl. xxiv. figs. 4 \& 6 , pl. xxv. figs. 1-4.

† Goppert figures and describes what he believes to be the fruit and male flowers of Walchia piniformis, in Die fos. Flora d. perm. Form. p. 239, pl. xlix.- the cones, figs. 1-10; the male flowers, figs. 11-14. See a'so Weiss, Flora d. juing. Stk. u. d. Rothl. p. 179, pl. xvii. fig. 1. The fruit of Tllmannia was described as far back as 1828 by H. Bronu, in Leonbard's Zeitschrift fiir Mineral. Band ii. p. 509, pl. iv, under the name of Cupressus Ullmanni. Goppert also figures, in his Permian Flora, similar cone-like fruits (pl. xlv. figs. 24, 25).

t Schimper, Traité d. Paléont. Végét. vol. ii. p. 358. 
structure in the latter which Göppert believed to be seeds, Schimper thinks are stamens, and this view I am inclined to adopt. These remarks show that the real affinities of Schutzia are very obscure.

Schimper regarded these fossils as belonging to a "coniferous plant, which was altogether paradoxical and without any analogy, either fossil or recent "*.

Although this is not a very satisfactory manner of disposing of Schutzia, the conclusions arrived at by Schimper may possibly be correct, though we have little positive evidence to support this opinion.

Large coniferous stems, with their internal structure beautifully preserved, are of frequent occurrence in various parts of the Calciferous Sandstones of Scotland. The remains of coniferous trees also occur in rocks of similar age in different parts of the globe; but notwithstanding their wide geographical distribution and frequency of occurrence, there is nothing definitely known regarding their fruit or foliage.

Prof. Dawson has described and figured a small coniferouslike branch from Tatamagouche (Carboniferous formation), which he has named Araucarites gracilis $\dagger$. This, he thinks, may possibly belong to his Dadoxylon materiarum $\downarrow$.

Some botanists regard the Trigonocarpons as the fruit of Conifers, but this opinion is not universally accepted $\$$.

The absence, however, of conclusive evidence as to the fruit and foliage of Palaezoic Conifere is not so surprising when we consider that the ancient pines most probably occupied the uplands of the then existing continents, and only the stems and larger branches would be able to resist the abrasion and decay of their long journey from the uplands to the tlats, where mud or sand was being deposited; and as proof of this, many of the stems of these trees are found imbedded in sandstone quarries, where they have been drifted.

The undoubted occurrence of the genus Schutzia so low down in the geological scale is of considerable importance; the discovery in the Calciferous Sandstones of a plant so closely related to a Permian species, is alınost without parallel.

* Loc. cit. p. 358.

+ Dawson, 'Acrdian Geology,' 2nd edit, p. 474, fig. 159 A (1868).

I Dawson, l. c. p. 424.

Stur also gives, in his 'Culm Flora' (p. 81, pl. xiv. tig. 4), a small figure and description of a fossil he has named Pinites antecedens. The specimen is small, and its union with the Coniferæ appears a little uucertain.

\$ Since writing the above, Prof. Williamson, in his Address at the British Association, has giren a résumé of this subject ('Nature,' Sept. 20, 1883). 
The small fossils which I previously described and placed in the genus Schutzia are different from the present example, and their real claim to this genus may perhaps be open to question*.

Schutzia Bennieana comes so near the Permian species, that it is only after very careful consideration I have given it a specific designation $\dagger$.

It gives me pleasure to name this plant after Mr. J. Bennie, to whom I owe so much for kind assistance in many points connected with my study of fossil botany.

Position and Locality. - In bituminous shale, water of Leith, opposite Kate's Mill, Midlothian ; Calciferous Sandstone series. Collected by Mr. James Bennie.

IX.-On the Fertilization of the Florider.

By Prof. F. Schmitz.

[Concluded from page 29.]

V.

THE preceding description has by no means exhausted all the modifications presented by the process of fertilization and fructification in the Floridea, as is shown by the fact that in almost every fresh genus that $I$ investigated $I$ detected new modifications of the previously observed processes. It is also sufficiently demonstrated by Bornet's statements with regard to Spyridia, Callymenia, Crouania, and other genera which I have hitherto been unable to examine. But the most important modifications of these processes have probably been shown in the foregoing in the described genera, which belong to the most different families of the Florideæ.

From this description it appears, however, that throughout, in the fertilization of the Floridea a material connexion exists between the male cell, the spermatium, and the cell which is developed into the sporigenous tissue of the cystocarp (the "nucleus" of systematic botany). A fertilizing influence of

* 'Trans. Roy. Soc. Edinb. vol. xxx. p. 545, pl. xxxi. figs. 10, 11, 12.

+ Schimper thinks the (?) Trigonocarpus Rossleri, Gein. (Neues Jahrb. 1867 , p. 288 , pl. iii. fig. 4), is an analogous fruit, but specifically distinct (Traité d. Puléont. Tégét, rol. ii. p. 358). 